\title{
2016: Et skæbneår \\ for Taiwan?
}

Af Peter Harmsen

Præsidentvalget i januar i Taiwan kan få afgørende betydning for forholdet mellem USA og Kina og for hele den sikkerhedspolitiske situation i det vestlige Stillehav. Alt afhænger af den kinesiske reaktion, efter at sejren gik til en kandidat fra et parti, der ikke har givet afkald på håbet om uafhængighed fra fastlandet. Efter otte forholdsvis stilfærdige år i Taiwanstrædet kan den nærmeste fremtid blive anderledes omskiftelig.

Taiwans hovedstad Taipei var det naturlige ground zero for præsidentvalget den 16. januar. Men i to andre hovedstæder var begivenhederne genstand for næsten lige så intens opmærksomhed: Washington og Beijing. Hvad der sker i Taiwan, er en af de mest centrale determinanter for det amerikansk-kinesiske forhold. Som en konsekvens heraf åbnes der for en omkalfatring af hele den strategiske situation i det vestlige Stillehav hvert fjerde år, når den taiwanske befolkning vælger ny leder. Det sker ikke hver gang, men potentialet er til stede.

2016 kunne være et af de år, hvor potentialet rent faktisk realiseres. Sejren gik til Tsai Ing-wen, en 59 år gammel jurist og forkvinde for det Demokratiske Progressive Parti (DPP). Det er et parti med rødder i den taiwanske uafhængighedsbevægelse, der voksede frem $i$ anden halvdel af forrige århundrede, og selv om DPP i nogen grad har nedtonet retorikken, har det stadig formel selvstændighed fra Kina som officielt mål. Kina har truet med en militær løsning, hvis Taiwan opgraderer den uafhængighed, som det allerede nyder de facto, til en uafhængighed de jure.

"Vi skal modsætte os alle separatisters stræben mod uafhængighed og forsøg på at skille Taiwan fra Kina og underminere fred og stabilitet," sagde Zhang Zhijun, lederen af den kinesiske regerings kontor for Taiwan-anliggender, i et interview på kontorets hjemmeside kort før valget. Han advarede ved samme lejlighed om, at 2016 kan blive et år med "komplekse forandringer og nye udfordringer" i forholdet hen over det cirka 150 kilometer brede Taiwanstræde.

Det er dårligt nyt for USA. Den amerikanske regering anerkender officielt Kina, men den har også offentligt forpligtet sig til at bidrage til Taiwans evne til at forsvare sig selv. Det manifesterede sig for eksempel i december med offentliggørelsen

Peter Harmsen er journalist på Weekendavisen og hyppig kommentator på DR. Han har boet og arbejdet som korrespondent i Kina, Taiwan og resten af Østasien i over 20 år og er forfatter til to bøger om kinesisk historie. 
af et amerikansk våbensalg på 1,83 mia. dollars til Taiwan. Hvis det nogen sinde skulle komme til krig i Taiwanstræedet, vil USA næsten uundgåeligt blive suget ind. Derfor er ro i området i USA's entydige interesse.

\section{Økonomien er vigtig}

Det er et spørgsmål, om USA får sit ønske opfyldt. Taiwans siddende præsident Ma Ying-jeou kunne efter to perioder og otte år i embedet ikke stille op til et nyt valg, men i det hypotetiske tilfælde, at han havde kandideret, ville det sikkert være gået hans parti, Kuomintang (KMT), endnu værre. Ved årsskiftet var mindre end 20 pct. af de taiwanske vælgere tilfredse med den måde, han havde bestridt sit hverv som statsoverhoved på. Ma er blevet beskyldt for både arrogance og lav effektivitet - en uheldig kombination for en leder.

På den baggrund er det nærliggende at fortolke nederlaget for KMT's kandidat, den venlige men farveløse Eric Chu, som udtryk for et ønske i vælgerkorpset om at se nye ansigter. Men det drejer sig nok mindre om personspørgsmål og mere om $ø$ konomi. I den forstand er øen - med et areal lidt større end Jylland og Fyn tilsammen og en befolkning på 23 millioner ikke meget anderledes end andre demokratier.

For sagen er, at tænderne er begyndt at blive sløve på den taiwanske tiger. Økonomien, der i storhedstiden i 1970'erne og 80 'erne nogle gange var oppe at røre ved tocifrede vækstrater, er nu endt på et næsten europæisk aktivitetsniveau. Og hvad der er endnu mere uheldigt set fra KMT's synsvinkel: Den almindelige borger føler sig ramt på sin personlige velfærd. Siden Ma Ying-jeou kom til magten i 2008, har indkomsterne ikke ændret sig markant, mens leveomkostningerne er steget næ- sten otte pct. Resultatet er reallønsnedgang.

"Når det går dårligt med økonomien lige op til et valg, så reagerer vælgerne ved at straffe den siddende regering. Det er klassisk demokratisk politik. Det indebærer også, at en stemme til Tsai ikke nødvendigvis bare er en stemme til hende, men i høj grad også en stemme imod Ma Ying-jeou," siger Kharis Templeman, som leder Taiwan Democracy Program, et forskningsprojekt på Stanford Universitetet.

Ma har på sin vis selv lagt op til den aktuelle situation ved at sætte sig yderst håndgribelige mål, da han bad vælgerne om at gøre ham til Taiwans leder. Han lovede økonomisk vækst på seks pct., og det har han ikke kunnet levere. I 2015 voksede bruttonationalproduktet med cirka en pct. Når han tidligere turde give så konkrete løfter, skyldtes det forventninger om den positive effekt af afspænding med Kina og øget interaktion med den dynamiske kinesiske økonomi.

Derfor er en kritik af Mas økonomiske politik også en kritik af hans Kina-politik. Kritikken forstærkes af tal, som tyder på voksende ulighed i Taiwan. Det giver grobund for en udbredt mistanke om, at det er de i forvejen stenrige, der har haft fordel af Mas forsonende linje over for Kina, fordi de har haft held til at investere på fastlandet og lukrere på de billige produktionsomkostninger. Taiwans arbejderklasse har derimod tabt, fordi beskæftigelsesmulighederne er rykket til fastlandet.

\section{Meget handler om Kina}

Sådan er det med Taiwan. Hvis man kradser lidt i overfladen, finder man, at meget i virkeligheden handler om Kina. For eksempel er det Tsai Ing-wens holdning til Kina, som nu har givet hende sejren - li- 
Mens Kina er forblevet autoritært, har Taiwan forvandlet sig til et modent og meget levende demokrati. Det er et af de lysende eksempler på et diktatorisk regime, som modstræbende men trods alt på forholdsvis fredsommelig vis gav afkald på magten og tillod demokrati uden den helt store voldseksplosion.

gesom det var hendes holdning til Kina, der kostede hende sejren for fire år siden. Dengang frygtede mange taiwanske vælgere, at hun var for rabiat, og at hun ville skabe røre i forholdet til kæmpen på den anden side af det smalle stræde. Og efter mange års erfaringer med den lunefulde kinesiske drage ønsker Taiwans befolkning helt overvejende at bibeholde status quo - det vil sige en form for uformel uafhængighed af Kina, uden at det bliver sagt højt.

Belært af nederlaget for fire år siden har Tsai i denne omgang anlagt en mere moderat tone. "Jeg skal nok lade være med at provokere Kina," sagde hun på tv kort før valget. "Der kommer ingen overraskelser." Alligevel har hun også understreget de områder, hvor hun adskiller sig fra sin forgænger, og ikke mindst fokuseret på en mere retfærdig fordeling af gevinsten fra det tættere forhold til Kina. "Mens jeg er fortaler for en konstruktiv udveksling og dialog med Kina, så vil jeg sørge for, at processen er demokratisk og gennemskuelig, og at de økonomiske fordele bliver ligeligt fordelt," sagde hun under et nyligt besøg i USA.

På et traditionelt venstre-højre kontinuum ligger DPP en del til venstre for KMT. Det gælder økonomisk og fordelingsmæssigt, og det gælder også kulturelt. Under Tsai er det for eksempel meget muligt, at Taiwan bliver det første samfund i Asien, som tillader homoseksuelle ægteskaber. Det er vigtige, men ikke essentielle forskelle. For i Taiwan er det holdningen til Kina, som definerer ideologisk ståsted. Det politiske kontinuum går fra ønsket om politisk union her og nu til krav om en formelt selvstændig taiwansk republik, også helst med det samme.

Det er først og fremmest langs dette kontinuum, at KMT og DPP placerer sig. KMT ønsker en forening med Kina på et eller andet ikke nærmere defineret tidspunkt ude i fremtiden, hvor samfundene på fastlandet og på Taiwan er blevet modne. DPP ønsker uafhængighed, men det skal også være engang i fremtiden, da det er klart, at Kina ikke vil tillade det nu. Selv om de to partier altså adskiller sig ret fundamentalt, er konsekvensen for den førte politik, at de begge bakker op om en fortsættelse af status quo indtil videre - hvilket er helt i pagt med befolkningens ønsker.

\section{Taiwans identitet}

I Kina er der ikke noget kontinuum, da den officielle diskurs kun tillader massiv tilslutning til kravet om politisk union, jo før jo bedre. Kina forsømmer desuden ingen lejlighed til at beskrive Taiwan som en uadskillelig del af sit territorium. Det har endda indført en lov, som formelt gør det illegalt for Taiwan at rive sig løs. Men den skråsikre kinesiske indstilling dækker over en broget historie, som kun kan efterlade tvivl om Taiwans egentlige identitet.

I 1895 tilfaldt Taiwan det japanske kejserrige som krigsbytte efter et vellykket felttog mod Kinas skrantende Qing-dynasti. Over de efterfølgende 50 år var Taiwan en japansk koloni. I 1945 var Kina, regeret af forgængeren til vore dages KMT, blandt Anden Verdenskrigs sejrende magter, og som belønning genvandt det kontrollen 
med Taiwan. Det var meget belejligt for KMT's leder Chiang Kai-shek, fordi han dermed havde et tilflugtssted, da han fire år senere måtte flygte fra fastlandet efter at have tabt en borgerkrig til Mao Zedongs kommunister.

Faktum er altså, at Taiwan i de seneste mere end 120 år kun har været regeret fra fastlandet $i$ en ganske kort periode lige efter anden verdenskrigs afslutning. Og siden 1949 har de to samfund på hver sin side af Taiwanstræedet bevæget sig længere og længere væk fra hinanden rent politisk. Mens Kina er forblevet autoritært, har Taiwan forvandlet sig til et modent og meget levende demokrati. Det er et af de lysende eksempler på et diktatorisk regime, som modstræbende men trods alt på forholdsvis fredsommelig vis gav afkald på magten og tillod demokrati uden den helt store voldseksplosion.

Demokratiseringen fandt sted i 1980'erne og 1990'erne, og allerede fra 2000 til 2008 befandt KMT sig i opposition. Det er et signal om det moderne KMT's respekt for demokratiets spilleregler, at i de seneste otte år, hvor partiet igen har haft magten, er Ma Ying-jeou aldrig gået længere i forhold til Kina, end den taiwanske opinion ville tillade. Det er blevet til i alt 23 aftaler med Kina under Ma og til et topmøde med Kinas præsident $\mathrm{Xi}$ Jinping i Singapore i november. Topmødet var især symbolsk, kulminerende i et langvarigt håndtryk mellem $\mathrm{Ma} o g \mathrm{Xi}$, men hvis Kina havde til hensigt at påvirke valget på Taiwan til fordel for KMT, så havde det ingen virkning.

"Det er muligt, at Ma Ying-jeou vil få en blidere behandling af historikerne, end hans aktuelle lave popularitet giver anledning til at formode. Desuden er han forholdsvis ung, og jeg kan forestille mig, at han ikke er klar til pension endnu. Der er måske en rolle for ham i taiwansk politik fremover, for eksempel i en eller anden rådgivende funktion inden for KMT," siger Kharis Templeman.

Det er ironisk, at Ma lige nu ikke får den ros, han måske fortjener for at have styrket de økonomiske bånd til Kina. Det er dobbelt ironisk, at båndene voksede med specielt stor hast under Taiwans første DPP-præsident, Chen Shui-bian, som ellers går for at være den mest Kina-uvenlige leder, øen har haft. Fra 2000, hvor Chen kom til magten, indtil han gik af $\mathrm{i}$ 2008, blev Taiwans eksport til Kina cirka 15-doblet.

Det skyldtes væksten i den kinesiske økonomi, som udfoldede sig særligt eksplosivt netop i den periode, og det havde også sin årsag i den omstændighed, at både Kina og Taiwan blev medlemmer af Verdenshandelsorganisationen WTO i begyndelsen af årtiet og dermed blev tvunget til at afvikle eksisterende toldskranker. Alt sammen mens Chen Shui-bian gik fra det ene skænderi til det andet med Kina. Der findes ikke noget bedre eksempel på, at den hårdkogte politiske retorik ofte kan bedrage, og at det økonomiske samkvem fortsætter upåvirket af krusninger på diplomatiets overflade.

\section{Afhængigheden af Kina}

Bagsiden af medaljen er, at Taiwan i dag er økonomisk dybt afhængigt af fastlandet. Kina står for næsten 23 pct. af Taiwans udenrigshandel, mens Taiwan omvendt kun står for cirka fire pct. af den kinesiske. Samtidig går cirka halvdelen af alle taiwanske udenrigsinvesteringer til Kina ifølge officielle tal, som sandsynligvis underdriver tendensen. Der er ingen tvivl om, hvem der har krammet på hvem. Kina kan snildt klare sig uden Taiwan. Men uden Kina ville tæppet blive revet 
væk under den taiwanske økonomi. Det benytter Kina sig af, fortæller Chen Chihjou, en politolog ved Taiwans førende forskningsinstitution Academia Sinica.

"Kina bruger taiwanske virksomheder til at lægge pres på den taiwanske regering, og det er også begyndt at bygge netværk omfattende regering og kapitalinteresser på begge sider af Taiwanstrædet. Disse netværk, som spinder både kinesiske og taiwanske virksomheder sammen med politiske interesser, er vokset stærkt i de seneste år, og de har haft en stor indvirkning på skiftende taiwanske regeringer. De vil også have det i deres magt at påvirke en DPP-regering," siger han.

Frygten for konsekvenserne af snigende $ø$ konomisk integration har i flere omgange fået taiwanske aktivister til at gribe til handling. Mest opsigtsvækkende skete det i foråret 2014, hvor unge repræsentanter for den såkaldte Solsikkebevægelse besatte det taiwanske parlament i flere uger. Det skete i protest over en omfattende aftale med Kina om handel med serviceydelser. Demonstranterne forlod parlamentet til sidst, men aftalen er to år senere stadig ikke ratificeret af Taiwan.

Det er den komplicerede situation, som Tsai Ing-wen har fået i arv med valgsejren. Tiden frem til den 20. maj, hvor hun formelt bliver indsat i præsidentembedet, kommer til at få afgørende betydning. Det er den periode, hvor hun har chancen for at formulere sin Kina-politik med udgangspunkt i valgresultatet, men uden at være bundet af hensynet til at skulle indynde sig over for flest mulige vælgere. Det er også det tidsrum, hvor de fleste iagttagere tror, hun vil gøre en indsats for at nå ud til fastlandet.

Og mens den kinesiske regering i månederne op til valget har nøjedes med at lægge pres på Tsai rent retorisk, er det muligt, at den nu vil gribe til mere konkret handling for at få hende med på indrømmelser. Det kunne for eksempel være en trussel om at fjerne nogle af de privilegier, som taiwanske landmænd nyder, når de skal eksportere deres produkter til fastlandet. Det kunne også komme i form af en reduktion i strømmen af kinesiske turister, der i Ma Ying-jeous embedsperiode er ankommet til Taiwan i millionvis, og som udgør en vigtig kilde til økonomisk vækst.

Et kinesisk pres på Tsai kunne lægge vægten på den såkaldte 92-konsensus. Det henviser til en forståelse mellem Kina og Taiwan fra begyndelsen af 1990'erne om at være enige om, at der kun findes ét Kina. Taiwans udgave af den forståelse tilføjer, at det er op til hver af de to sider at definere nærmere, hvad 'ét Kina' egentlig indebærer. Den taiwanske tilføjelse er mest ment som en garanti for, at Kina ikke bruger 92-konsensus som et springbræt til politisk union på sine betingelser.

Men selv den mere moderate taiwanske version af 92-konsensus er sikkert politisk umulig for Tsai at acceptere på grund af hendes bagland, der også omfatter ortodokse tilhængere af uafhængighed og ko-opterede medlemmer af Solsikkebevægelsen - helt bortset fra, hvad hun af ideologiske årsager selv måtte mene om spørgsmålet. Men selv om der allerede nu er lagt op til uenighed med Kina, kommer de indledende tvister med stor sandsynlighed til at foregå bag facaden, ifølge Tung Chen-yuan, en politolog fra det $\mathrm{Na}$ tionale Cheng Chi Universitet i Taipei.

"Selv om den kinesiske regering har tænkt sig at lægge betydeligt pres på Tsai, så forstår den også udmærket, at uden forhandlinger og dialog bliver det meget vanskeligt at få indrømmelser ud af hende. Hun har jo lige vundet et valg og op- 
nået et mandat, og der går fire år før det næste valg. Det, Kina nok vil gøre, er at forsøge at lægge diskret pres på Tsai via USA. Tsai vil omvendt også benytte sig af USA som kommunikationskanal i forhold til Kina. Vi vil se en form for indirekte forhandling på den måde frem til maj," siger han.

Erfaringerne fra sidste gang, DPP havde vundet præsidentposten, er ikke gode. Dengang for 16 år siden var det Chen Shui-bian, der havde bragt sejren i hus. Hans tiltrædelsestale var allerede godkendt af USA, og den slog iagttagerne med sin moderate tone. Men Kina nægtede at spille med. Beijing havde allerede dannet sig en mening om Chen som en farlig uafhængighedstilhænger, og han blev afvist med det samme, nærmest per refleks. Senere, efterhånden som Chen fandt ud af, at han alligevel ikke havde noget at tabe, blev han selv langt mere kompromisløs over for Kina.

"Mit håb er, at kineserne vil bruge perioden frem til 20. maj på at finde ud af, hvad slags person hun er, og hvordan man kan arbejde sammen med hende. Når vi først passerer 20. maj, tror jeg, chancen for at se hinanden an er forbi. Hvis de ikke finder ud af noget inden hendes tiltræden, så tror jeg, de står foran fire vanskelige år, måske endda otte år, hvis hun bliver genvalgt," siger Steve Goldstein, en ekspert i forholdet mellem Kina og Taiwan fra Harvard.

Et flertal af den taiwanske befolkning stoler på, at Tsai Ing-wen ikke vil ofre de nationale interesser i forhandlinger med Kina. Det viser meningsmålinger. Kunne det tænkes, at Tsai Ing-wen blev Taiwans Nixon - en politiker, som man trygt kan overlade et forhandlingsmandat til, fordi hun $\mathrm{i}$ årevis har demonstreret, at hendes loyalitet over for hjemmefronten ikke er i tvivl? Både ja og nej, ifølge Tung Chenyuan.

"Hun er ligesom Nixon i den forstand, at han også havde opbygget en betydelig indenrigspolitisk tillid som en person, der ikke ville sælge ud af de nationale interesser. Men desuden nød han godt af et sammenfald i strategiske interesser mellem USA og Kina. Selv om Tsai også har oparbejdet indenrigspolitisk tillid, så er der ikke noget sammenfald af strategiske interesser mellem Kina og Taiwan, som kan hjælpe dem til en større forståelse på kort sigt," siger han.

\section{Et stemningsskift}

Der er desuden en anden faktor, som forhindrer tilnærmelse. I de seneste år er der sket et vigtigt stemningsskift i Taiwan. Ifølge de seneste tal fra midten af 2015 opfatter 59,0 pct. af øens befolkning sig som taiwanere, ifølge Valgstudiecentret på Taipeis Cheng Chi Universitet. Det er op fra 17,6 pct. i 1992, da centret første gang stillede det spørgsmål i en rundspørge. I den samme 23-årige periode er andelen, der beskriver sig selv som kinesere, dalet fra 25,5 til 3,3 pct. Den andel, der opfatter sig som både taiwanere og kinesere, er faldet fra 46,4 til 33,7 pct.

Udviklingen er ikke til at tage fejl af: Den taiwanske identitet er specielt stærk blandt de unge, for hvem Kina er det rene og skære udland. "Taiwan er under forandring. De unge mellem 20 og 29 er allermest bevidste om at være taiwanske. Jo længere DPP kan regere, jo mere vil Taiwan-bevidstheden have mulighed for at bundfælde sig og gøre det endnu mere vanskeligt for Kina at have med øen at gøre," siger Harvards Goldstein.

Selv hvis Kina gennemfører mere fundamentale demokratiske reformer, hvilket er yderst usandsynligt inden for en over- 
skuelig fremtid, vil taiwanerne nok stadig modsætte sig politisk union. De problemer, som Hongkong har oplevet, siden Kina overtog kontrollen i 1997, har heller ikke hjulpet. Kina har opstillet cirka 1.500 missiler vendt mod Taiwan, men det vinder man ikke hearts and minds ved. I den forstand er tiden ikke på Kinas side. Og forslag som for eksempel at fastfryse situationen i 50 år og så vende tilbage og se, hvad der da kan gøres, har ikke mange chancer for succes.

"Hvis de seneste 50 år er en rettesnor, så tyder alt på, at de 50 år bare vil give Taiwan mulighed for at udvikle en endnu mere distinkt identitet og dermed gøre fredelig union endnu vanskeligere. Derfor kan det være, at Kina bliver nødt til at acceptere et beskedent succeskriterium og simpelt hen stille sig tilfreds med at undgå, at Taiwan erklærer sig formelt uafhængigt," siger Timothy Rich, en Taiwan-ekspert ved Western Kentucky University.

Er det realistisk? Har den kinesiske ledelse politisk kapital til at nedtone sine krav til Taiwan uden at udsætte sig for angreb fra rivaliserende grupper? Der er ingen, der med sikkerhed ved, hvor magtfuld Xi Jinping er. Endnu værre: Selv hvis Xi virkelig er den mest magtfulde kinesiske politiker siden Deng Xiaoping, sådan som nogle iagttagere påstår, er der heller ingen, som præcist kan sige, hvad han vil bruge magten til. Kina er i sandhed en uigennemtrængelig black box. I kombination med, at Kina samtidig også er den vigtigste dererminant for situationen i Taiwan-strædet, er der lagt op til betydelig usikkerhed om, hvordan hele situationen vil udvikle sig.

Problemet kompliceres af den offentlige opinion i Kina. Der er stærke følelser i den kinesiske befolkning, når det gælder en række udenrigspolitiske spørgsmål, herunder især forholdet til Japan og Taiwan. Det er i en vis forstand en kunstig opinion, skabt af det kinesiske kommunistparti gennem uddannelsessystemet og de statskontrollerede medier. Men det er ikke desto mindre en opinion, som er stærk og vanskelig at kontrollere.

Vrede demonstranter har i de seneste år gentagne gange hærget kinesiske bykerner med krav om en hårdere kurs over for Japan. Det er ikke utænkeligt, at et Taiwan, som styrede mod uafhængighed, ville fremkalde lignende protester i Kina. Nogle iagttagere vil endda gå så langt som til at påstå, at det kinesiske regime ikke ville kunne overleve tabet af Taiwan, specielt ikke hvis det var kombineret med mere generel svækkelse på en række områder.

"Der kan opstå en situation med risiko for væbnet konflikt, hvis Kina havner $\mathrm{i}$ alvorlige vanskeligheder, hvor diverse økonomiske bobler brister og der forekommer omfattende intern uro med udfordring af det kommunistiske regime. Men hvis der ikke indtræffer internt kaos i Kina, så ser jeg ikke nogen risiko for væbnet konflikt i Taiwanstræetet med tilhørende amerikansk involvering i løbet af de kommende fire eller endda otte år med en DPP-præsident," siger Chen Chih-jou fra Academia Sinica. 